\title{
50 EV MASS SPECTRA OF 1- AND 3-n-ALKYL-SUBSTITUTED CYCLOPENT-1-ENES
}

In literature there are few mass spectral data available for hydrocarbons of the cyclopentene series.

Praet [ $\left.{ }^{1}\right]$ has investigated the fragmentation of 1-methylcyclopentene, methylenecyclopentane and other isomeric to them $\mathrm{C}_{6} \mathrm{H}_{10}$ unsaturated hydrocarbons at various energies of bombarding electrons. The API cata$\log \left[{ }^{2}\right]$ and other compilations $\left[{ }^{3,4}\right]$ include mass spectra of $1-, 3-, 4-$ methyl- and 1- and 3-ethylcyclopentenes. The base peak in their spectra corresponds to an ion $\left(\mathrm{C}_{5} \mathrm{H}_{7}\right)+$ formed by the elimination of the methyl or ethyl group from the molecular ion. Since the mass spectra of isomeric methyl- and ethylcyclopentenes are very similar, the common degradation paths of molecular ions, supposed to undergo double bond isomerization via hydrogen rearrangements before fragmentation, may be assumed, analogically to positional isomers of many other olefins $\left.{ }^{5-8}\right]$.

The fragmentation regularities observed for methyl- and ethylcyclopentenes only, are inadequate for elucidating principal fragmentation paths and identifying possibilities of higher isomeric homologs in this series. The fundamental data for solving these problems - mass spectra of higher cyclopentenes - have not been described so far. As they are of considerable theoretical and practical interest, we have recorded mass spectra of various monosubstituted cyclopentenes at various energies of bombarding electrons and investigated the effect of the side chain length, structure and position on the fragmentation process. In this report, the regularities found in $50 \mathrm{eV}$ mass spectra of 1 - and 3-nalkylcyclopentenes $\mathrm{C}_{6}-\mathrm{C}_{12}$ with the position and length of the $n$-alkyl group in a side chain, are presented. This work was carried out as a part of the program of a systematic investigation of the physico-chemical properties of unsaturated hydrocarbons. The mass spectra obtained can be used for the identification of individual compounds when analysing complex olefinic mixtures by chromato-mass-spectrometry.

\section{Experimental}

The compounds investigated were $n$-alkylcyclopentanes, 1 - and $3-n$ alkylcyclopent-1-enes with methyl...n-hexyl group in a side chain and 1-n-heptylcyclopentene-1-ene. 
1-n-alkylcyclopent-1-enes were prepared by dehydration with iodine of the corresponding 1-n-alkylcyclopentan-1-ols, obtained by the Grignard reaction on cyclopentanone $\left[{ }^{9,10}\right]$.

3-n-alkylcyclopent-1-enes were prepared by interaction of corresponding Grignard reagents with 3-chlorocyclopent-1-ene [11].

$n$-Alkylcyclopentanes were obtained by hydrogenation of $n$-alkylcyclopentenes.

The synthesized hydrocarbons were purified by rectification and preparative gas chromatography on 1,2,3-tris-(2-cyanoethoxy)-propane or apiezon $L\left[{ }^{i 2}\right]$. Their purity, determined on capillary columns $(45-80 \mathrm{~m}$; $0.25 \mathrm{~mm}$ ) coated with squalane, apiezon $L$ or polyethylene glycol 4000 , varied within the limits of $97.4-99.9$ per cent.

The mass spectra were run on a modified $\left[{ }^{13,14}\right] \mathrm{MH}-1303$ mass spectrometer with an oscillographic recorder. The electron beam energy was $50 \mathrm{eV}$, ion accelerating voltage $2.2 \mathrm{kV}$, emission current $0.75 \mathrm{~mA}$, temperature in the inlet reservoir and ion source $-200^{\circ} \mathrm{C}$. For every compound at least 3 mass spectra were recorded. Parallel spectra showed differences within the limits of $1-2.5$ per cent (relative). The differences in the spectra taken through longer time intervals were on an average 5-10 per cent (rel.). MINSK 22 or 23 computer was used to calculate and tabulate the mass-spectral data. The relative peak intensities were calculated as a percentage of the base peak (B) and of the total ion intensities $(\Sigma)$ in the mass range from 12 mass units (m. u.) up to two $\mathrm{m}$. u. higher of the molecular ion peak $(M+2)$. Stability of the molecular ion $\left(\mathrm{W}_{\mathrm{m}}\right)$ was calculated from the formula:

$W_{\mathrm{m}}=\frac{\mathrm{I}_{\mathrm{moI}}}{\mathrm{I}_{\mathrm{moI}}+\Sigma \mathrm{I}_{\mathrm{rag}}}$, where $\mathrm{I}_{\mathrm{mol}}-$ total intensity of the molecular ion, included its isotopic ${ }^{13} \mathrm{C}$ ion $\left[{ }^{15}\right]$,

$\Sigma I_{\text {frag }}$ - sum of peak heights of all fragment ions.

In addition, total intensities of homologous series of ions $\left(\mathrm{C}_{n} \mathrm{H}_{2 n+1}\right)^{+}$, $\left(\mathrm{C}_{n} \mathrm{H}_{2 n}\right)^{+},\left(\mathrm{C}_{n} \mathrm{H}_{2 n-1}\right)^{+},\left(\mathrm{C}_{n} \mathrm{H}_{2 n-2}\right)^{+}$and $\left(\mathrm{C}_{n} \mathrm{H}_{2 n-3}\right)^{+}-\Sigma 43, \Sigma 42, \Sigma 41$, $\Sigma 68$ and $\Sigma 67$ and total intensities of ions with the same number of carbon atoms $-\Sigma C_{1}, \Sigma C_{2}$, etc., were calculated. From published data available for some compounds, the same characteristics were calculated, too. The latter coincided well with our experimental data. The peak intensities in the text, if not indicated otherwise, are expressed in per cent of the total ion intensities.

\section{Results and discussion}

Mass spectra obtained are given in Tables $1-3$. Peaks with intensities less than 1 per cent (in B) are omitted.

Mass spectra of $n$-alkylcyclopentenes reveal great differences in fragment ion distribution and in molecular ion intensity, as compared to those of $n$-alkylcyclopentanes with an identical side chain.

Due to the stabilizing effect of double bond $\pi$-electrons, the $W_{m}$ values of 1-n-alkylcyclopentenes are on an average three times higher than those of $n$-alkylcyclopentanes with an identical side chain (Fig. 1).

1- and 3-methyl- as well as 1- and 3-ethylcyclopentenes have close $W_{m}$ values, but there are certain differences between the $W_{m}$ values of higher 1- and 3-n-alkylcyclopentenes, showing higher stability (up to 1.5 times) of 1-n-alkylcyclopentene molecular ions.

In accordance with the general rule, the relative abundances of molecular peaks decrease with the lengthening of $n$-alkyl side chain 


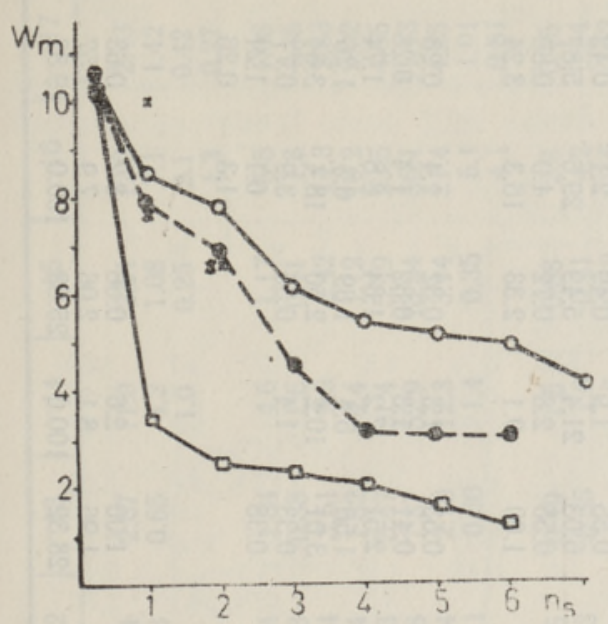

Fig. 1. Stability $W_{\mathrm{m}}$ of n-alkylcyclopentenes and -pentanes upon electron impact at $50 \mathrm{eV}$.

$n_{s}$ - number of carbon atoms in a side chain, $O-1-n$-alkylcyclopent-1-enes, - 3-n-alkylcyclopent-1-enes, $\oplus$ cyclopentene, $\square-n$-alkylcyclopentanes, +1 - cyclopentane,,$+{ }^{*}$ - literature data for 1- and 3-alkylcyclopentenes.
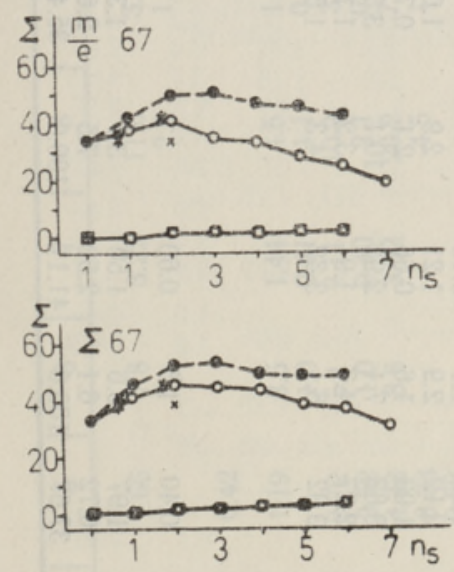

Fig. 3. Dependence of the intensity of the peak with $\mathrm{m} / \mathrm{e} 67$ and of $\Sigma 67$ on the number of carbon atoms ill a side chain $n_{\kappa}$.

Designation as in Fig. 1. $\Sigma 41$ make about 40 per cent (Fig. 2), and exceed four times those of 1 - and $3-n$-alkylcyclopentenes with the same $n_{s}^{*}(10-13 \%)$. The intensities of base peaks - m/e 41 and 69 vary in the limits of $10-15$ per
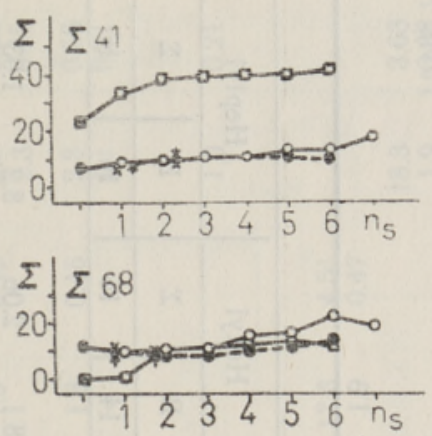

Fig. 2. Dependences of $\Sigma 41$ and $\Sigma 68$ on the number of carbon atoms in a side chain $n_{s}$.

Designation as in Fig. 1 .

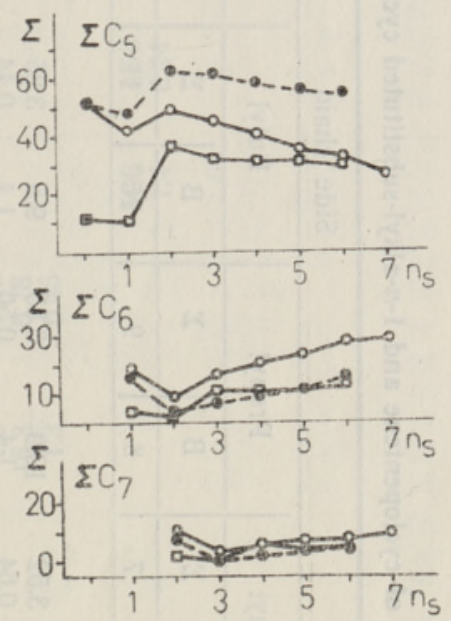

Fig. 4. Dependences of $\Sigma \mathrm{C}_{5}$, $\Sigma \mathrm{C}_{6}$ and $\Sigma \mathrm{C}_{7}$ on the number of carbon atoms in a side chain $n_{s}$.

Designation as in Fig 1.

$\mathrm{C}_{1} \ldots \mathrm{C}_{6}$ from 3 to 1 and from 8 to 3 per cent for $n$-alkylcyclopentanes and -pentenes, respectively (Fig. 1).

More intensive peaks in the mass spectra of $n$-alkylcyclopentanes with two to six carbon atoms in a side chain correspond to ions $\left(\mathrm{C}_{n} \mathrm{H}_{2 n-1}\right)+$ with $\mathrm{m} / \mathrm{e} 41$, 55,69 , etc. The sums

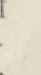




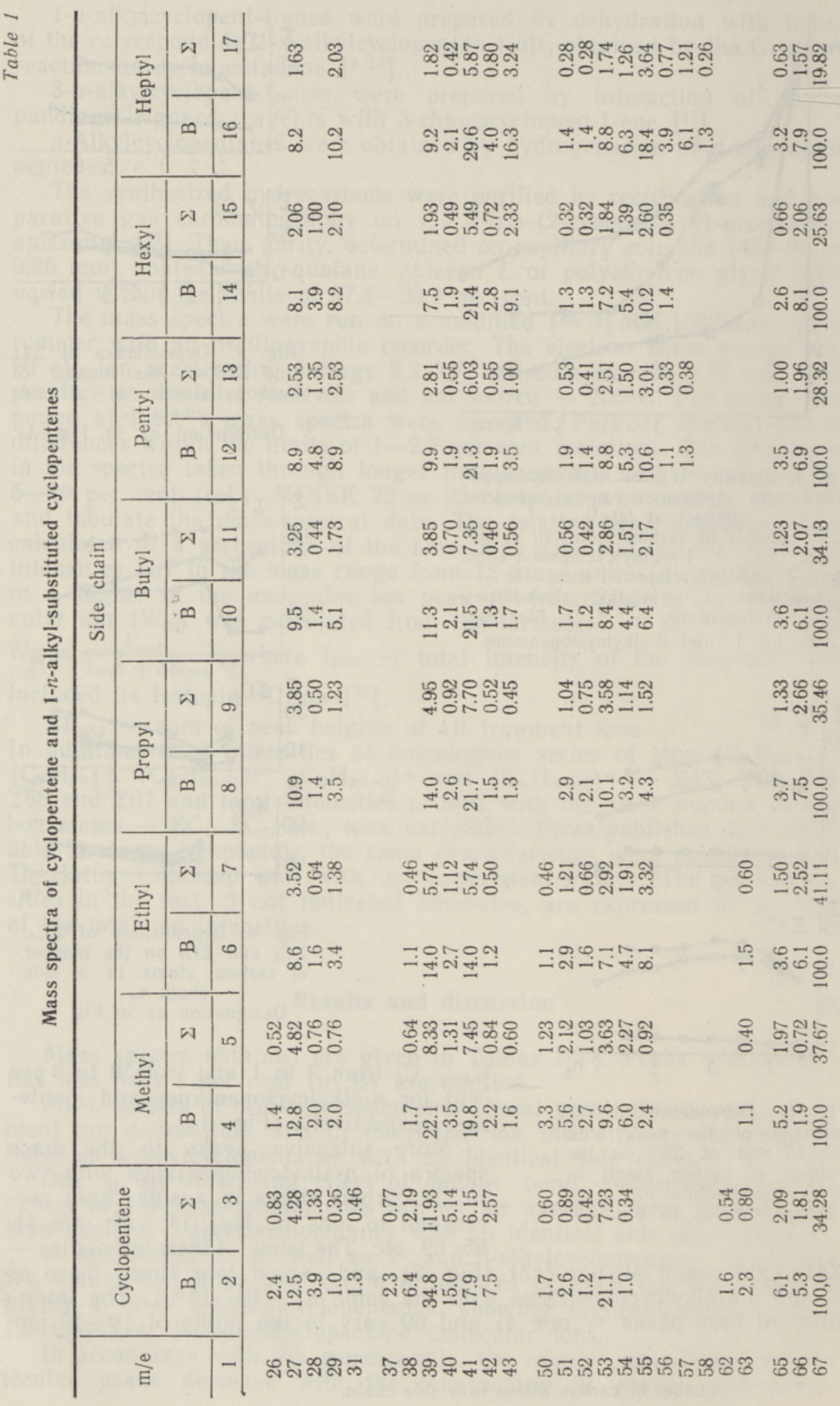




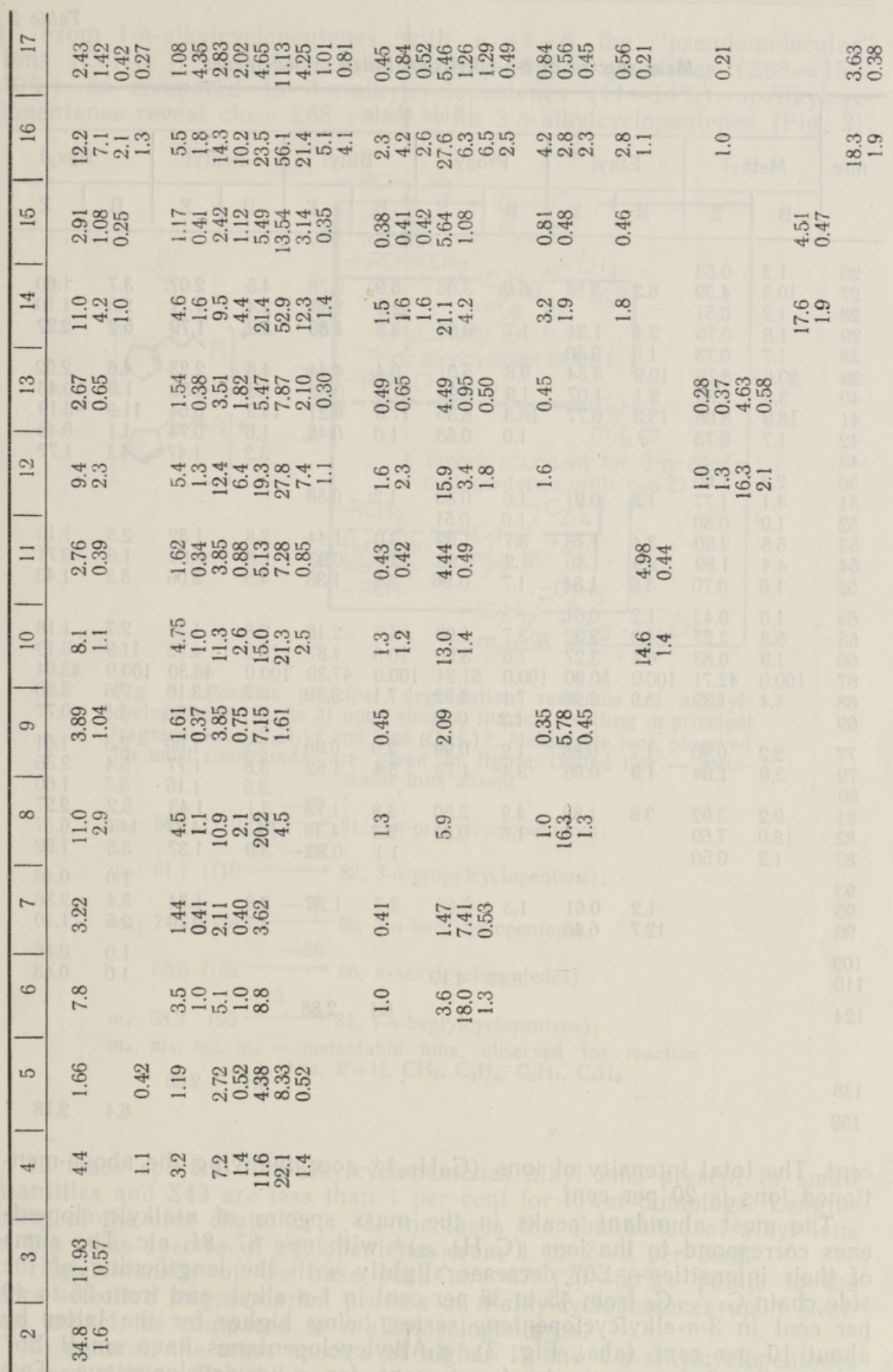

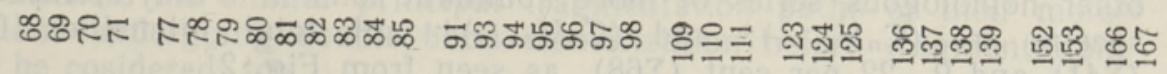


Mass spectra of 3 - $n$-alkyl-substituted cyclopentenes

\begin{tabular}{|c|c|c|c|c|c|c|c|c|c|c|c|c|}
\hline \multirow{3}{*}{$\mathrm{m} / \mathrm{e}$} & \multicolumn{12}{|c|}{ Side chain } \\
\hline & \multicolumn{2}{|c|}{ Methyl } & \multicolumn{2}{|c|}{ Ethyl } & \multicolumn{2}{|c|}{ Propyl } & \multicolumn{2}{|c|}{ Butyl } & \multicolumn{2}{|c|}{ Pentyl } & \multicolumn{2}{|r|}{ Hexyl } \\
\hline & B & $\Sigma$ & B & $\Sigma$ & B & $\Sigma$ & B & $\Sigma$ & B & $\Sigma$ & B & $\Sigma$ \\
\hline 26 & 1.2 & 0.53 & & & & & & & & & & \\
\hline 27 & 10.3 & 4.39 & 6.2 & 3.18 & 6.0 & 3.06 & 5.9 & 2.78 & 4.5 & 2.07 & 3.7 & 1.60 \\
\hline 28 & 1.2 & 0.51 & & & & & 2.9 & 1.36 & 2.4 & 1.11 & 2.5 & 1.10 \\
\hline 29 & 1.8 & 0.76 & 2.4 & 1.24 & 1.7 & 0.86 & 3.5 & 1.66 & 3.9 & 1.79 & 5.2 & 2.27 \\
\hline 38 & 1.7 & 0.73 & 1.0 & 0.50 & & & & & & & & \\
\hline 39 & 20.6 & 8.79 & 10.9 & 5.54 & 9.8 & 5.01 & 9.4 & 4.44 & 4.8 & 2.23 & 4.6 & 2.02 \\
\hline 40 & 3.3 & 1.39 & 2.1 & 1.07 & 1.9 & 0.96 & 1.8 & 0.85 & 1.3 & 0.58 & 1.0 & 0.43 \\
\hline 41 & 18.9 & 8.06 & 13.3 & 6.77 & 16.3 & 8.35 & 17.3 & 8.21 & 14.3 & 6.64 & 11.9 & 5.19 \\
\hline 42 & 1.7 & 0.73 & & & 1.0 & 0.53 & 1.0 & 0.48 & 1.6 & 0.74 & 1.1 & 0.48 \\
\hline 43 & & & & & & & & & 3.2 & 1.47 & 4.1 & 1.77 \\
\hline 50 & 2.3 & 1.00 & & & & & & & & & & \\
\hline 51 & 4.1 & 1.77 & 1.8 & 0.91 & 1.6 & 0.83 & 1.2 & 0.58 & & & & \\
\hline 52 & 1.9 & 0.80 & & & 1.0 & 0.51 & & & & & & \\
\hline 53 & 6.8 & 2.90 & 3.4 & 1.73 & 3.7 & 1.92 & 3.0 & 1.44 & 2.8 & 1.32 & 2.5 & 1.10 \\
\hline 54 & 4.4 & 1.89 & 2.9 & 1.46 & 1.9 & 0.96 & 2.0 & 0.93 & 1.8 & 0.84 & 1.6 & 0.71 \\
\hline 55 & 1.6 & 0.70 & 3.6 & 1.84 & 1.7 & 0.96 & 2.9 & 1.36 & 4.5 & 2.06 & 3.3 & 1.43 \\
\hline 63 & 1.0 & 0.43 & 1.2 & 0.61 & & & & & & & & \\
\hline 65 & 5.3 & 2.27 & 4.0 & 2.02 & 3.7 & 1.92 & 4.6 & 2.16 & 2.8 & 1.32 & 2.7 & 1.18 \\
\hline 66 & 1.9 & 0.83 & 6.4 & 3.27 & 7.6 & 3.90 & 10.3 & 4.87 & 10.2 & 4.72 & 11.9 & 5.19 \\
\hline 67 & 100.0 & 42.71 & 100.0 & 50.90 & 100.0 & 51.24 & 100.0 & 47.39 & 100.0 & 46.30 & 100.0 & 43.64 \\
\hline $\begin{array}{l}68 \\
69\end{array}$ & 4.4 & 1.89 & 5.9 & 2.98 & $\begin{array}{l}7.1 \\
1.2\end{array}$ & $\begin{array}{l}3.62 \\
0.61\end{array}$ & 7.1 & 3.36 & $\begin{array}{l}6.7 \\
1.1\end{array}$ & $\begin{array}{l}3.10 \\
0.50\end{array}$ & $\begin{array}{l}7.6 \\
1.8\end{array}$ & $\begin{array}{l}3.30 \\
0.77\end{array}$ \\
\hline 77 & 2.2 & 0.90 & 1.7 & 0.88 & 1.9 & 0.99 & 2.0 & 0.96 & 2.2 & 1.00 & 2.3 & 1.01 \\
\hline 79 & 3.8 & 1.64 & 1.9 & 0.96 & 3.4 & 1.73 & 3.4 & 1.62 & 3.8 & 1.77 & 5.4 & 2.36 \\
\hline 80 & & & & & & & & & 2.5 & 1.16 & 3.7 & 1.60 \\
\hline 81 & 9.2 & 3.92 & 3.6 & 1.83 & 4.9 & 2.50 & 3.8 & 1.78 & 3.1 & 1.43 & 5.2 & 2.27 \\
\hline 82 & 18.0 & 7.69 & & & 1.6 & 0.81 & 9.3 & 4.38 & 10.5 & 4.87 & 14.6 & 6.37 \\
\hline 83 & 1.2 & 0.50 & & & & & 1.1 & 0.53 & 3.0 & 1.37 & 3.5 & 1.52 \\
\hline 93 & & & & & & & & & & & 1.0 & 0.46 \\
\hline 95 & & & 1.2 & 0.61 & 1.3 & 0.66 & 2.7 & 1.28 & 3.8 & 1.74 & 5.4 & 2.36 \\
\hline 96 & & & 12.7 & 6.45 & & & & & 1.7 & 0.79 & 2.5 & 1.10 \\
\hline 109 & & & & & & & & & & & 1.0 & 0.46 \\
\hline 110 & & & & & 8.15 & 4.17 & & & & & 1.0 & 0.43 \\
\hline 124 & & & & & & & 6.1 & 2.88 & & & & \\
\hline
\end{tabular}

cent. The total intensity of ions $\left(\mathrm{C}_{n} \mathrm{H}_{2 n}\right)+$ accompanying the above-mentioned ions is 20 per cent.

The most abundant peaks in the mass spectra of n-alkylcyclopentenes correspond to the ions $\left(\mathrm{C}_{n} \mathrm{H}_{2 n-3}\right)^{+}$with $\mathrm{m} / \mathrm{e} 67,81$, etc. The sums of their intensities $-\Sigma 67$ decrease slightly with the lengthening of the side chain $\mathrm{C}_{3} \ldots \mathrm{C}_{6}$ from 45 to 38 per cent in 1-n-alkyl-and from 55 to 49 per cent in 3-n-alkylcyclopentene series, being higher for the latter by about 10 per cent (abs., Fig. 3). n-Alkylcyclopentanes have small $\Sigma 67$ values that increase up to 4 per cent for $n$-hexylcyclopentane. Two other homologous series of more abundant ions in $n$-alkylcyclopentene spectra. are $\left(\mathrm{C}_{n} \mathrm{H}_{2 n-1}\right)^{+}$and $\left(\mathrm{C}_{n} \mathrm{H}_{2 n-2}\right)^{+}$with total intensities 10-13 $(\Sigma 41)$ and $9-22$ per cent $(\Sigma 68)$, as seen from Fig. 2. 
From 1-n-alkylcyclopentenes with $n_{s}=4-6$ the "pseudomolecular" ions $\left(\mathrm{C}_{n} \mathrm{H}_{2 n-2}\right)^{+}$are formed in slightly higher quantities ( $\Sigma 68=15$ $20 \%)$ as compared to 3-n-alkylcyclopentenes $(11-14 \%)$. n-Alkylcyclopentanes reveal close $\Sigma 68$ values with 3 -n-alkylcyclopentenes (Fig. 2).

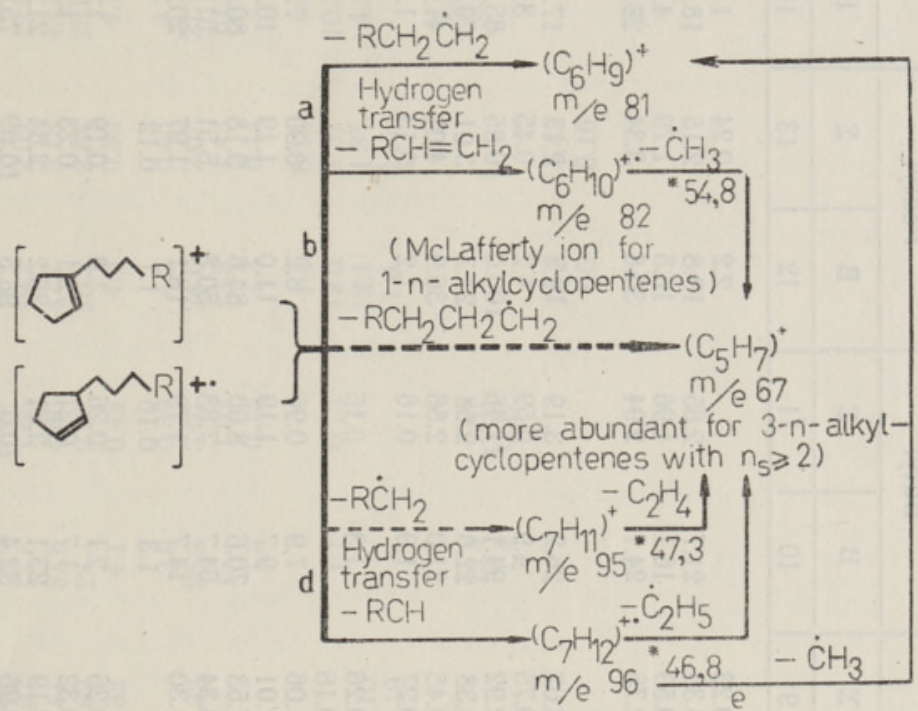

Fig. 5. Possible principal degradation reactions of $n$-alkylcyclopentenes $\left(n_{s} \geqslant 3\right)$ upon electron impact, resulting in principal fragment ions $\left(\mathrm{C}_{5} \mathrm{H}_{7}\right)+$ and ions $\left(\mathrm{C}_{6} \mathrm{H}_{9}\right)+$. Metastable ions, observed for most compounds, are given in figure. Dotted line - metastable ions absent.

$\mathrm{m}_{\mathrm{a}}: 59.7(110 \stackrel{-29}{\longrightarrow} 81,3-n$-propylcyclopentene);

$\mathrm{m}_{\mathrm{b}}: 61.1(110 \stackrel{-28}{\longrightarrow} 82,3$ - $n$-propylcyclopentene);

$\mathrm{m}_{\mathrm{d}}: 74.3(124 \stackrel{-28}{\longrightarrow} 96,3-n$-butylcyclopentene);

$60.6(152 \stackrel{-56}{\longrightarrow} 96, n$-hexylcyclopentenes $) ;$

$\mathrm{m}_{\mathrm{e}}: 68.3 \quad(96 \stackrel{-15}{\longrightarrow} 81,1-n$-heptylcyclopentene $)$;

$\mathrm{m}_{\mathrm{a}}, \mathrm{m}_{\mathrm{b}}, \mathrm{m}_{\mathrm{d}}, \mathrm{m}_{\mathrm{e}}-$ metastable ions, observed for reaction a, b, d, e, $\mathrm{R}=\mathrm{H}, \mathrm{CH}_{3}, \mathrm{C}_{2} \mathrm{H}_{5}, \mathrm{C}_{3} \mathrm{H}_{7}, \mathrm{C}_{4} \mathrm{H}_{9}$.

In mass spectra of $n$-alkylcyclopentenes alkyl ions present in small quantities and $\Sigma 43$ are less than 1 per cent for lower homologs. Lengthening of the side chain $\mathrm{C}_{4} \ldots \mathrm{C}_{6}$ increases the abundance of alkyl ions in the mass spectra of cyclopentenes from 1 to $2-3$ per cent.

High intensity of the base peak m/e $67(20-50 \%)$ points to the more selective fragmentation process of $n$-alkylcyclopentenes upon electron impact, as compared to $n$-alkylcyclopentan es.

In general, the mass spectra of higher 1 - and 3 -n-alkylcyclopentenes are very similar. For this reason, equally to isomeric methyl- and ethylcyclopentenes, the similar principal fragmentation paths of their molecular ions undergoing double bond isomerization before iragmentation, are to be cosidered, too. 


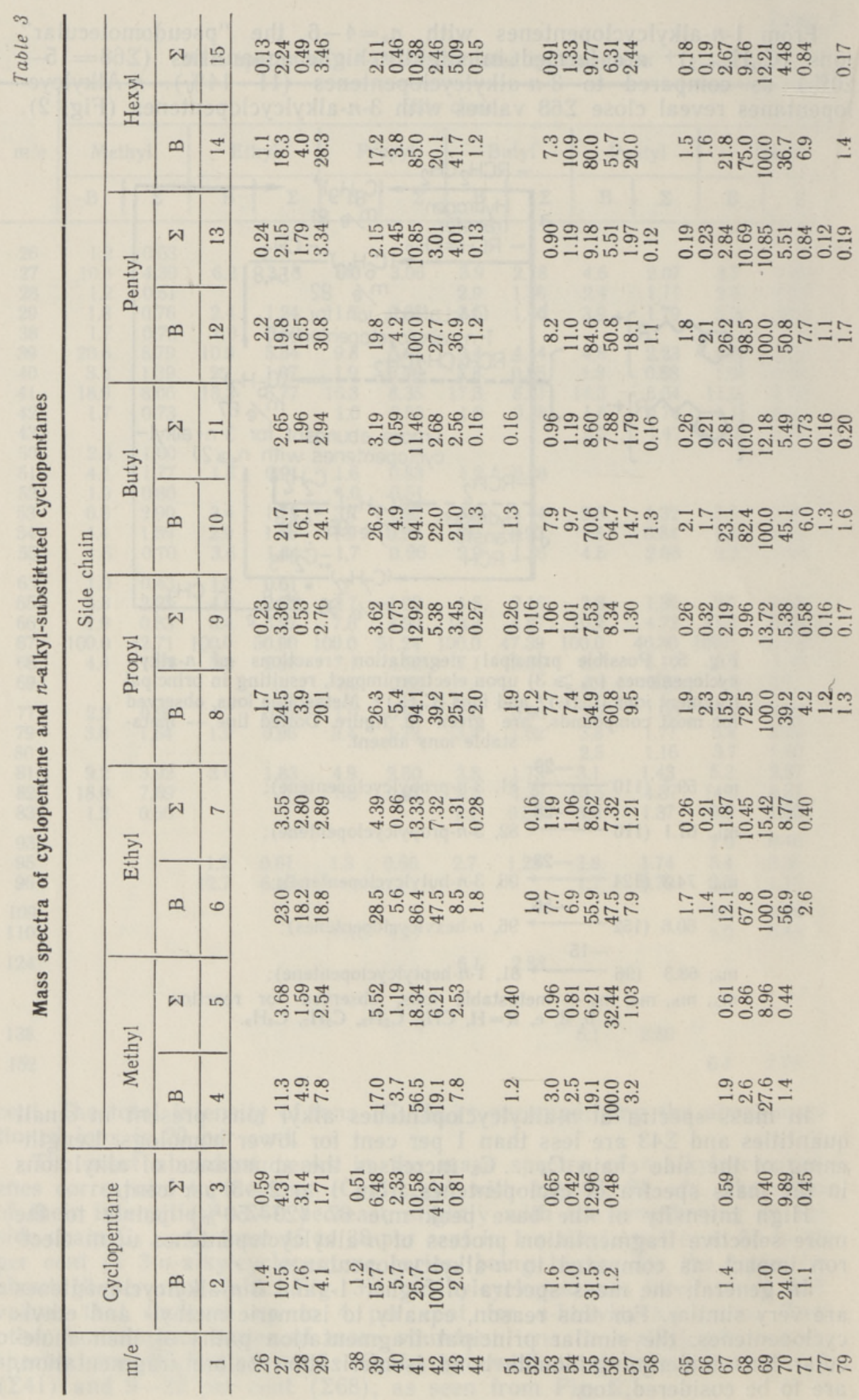




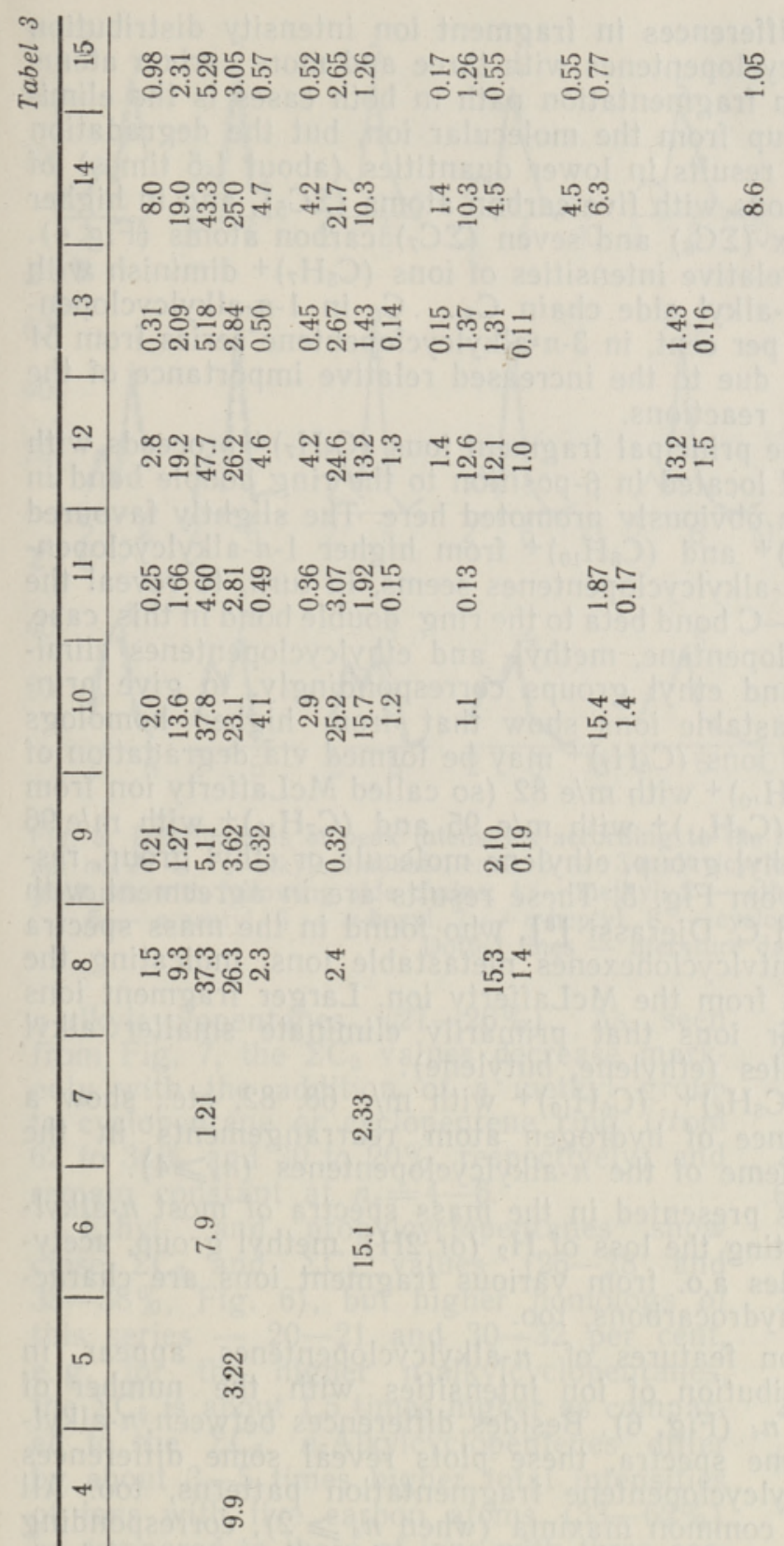

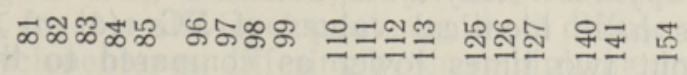


There appear some differences in fragment ion intensity distribution between 1 - and 3-n-alkylcyclopentenes with three and more carbon atoms in a side chain. The main fragmentation path in both cases is the elimination of the $n$-alkyl group from the molecular ion, but the degradation of 1- $n$-alkylcyclopentenes results in lower quantities (about 1.5 times) of ions $\left(\mathrm{C}_{5} \mathrm{H}_{7}\right)+$ as well as ions with five carbon atoms $\left(\Sigma \mathrm{C}_{5}\right)$, and in higher quantities of ions with six $\left(\Sigma \mathrm{C}_{6}\right)$ and seven $\left(\Sigma \mathrm{C}_{7}\right)$ carbon atoms (Fig. 4$)$. In Fig. 3 it is seen that relative intensities of ions $\left(\mathrm{C}_{5} \mathrm{H}_{7}\right)+$ diminish with the lengthening of the $n$-alkyl side chain $\mathrm{C}_{3} \ldots \mathrm{C}_{6}$ in 1 -n-alkylcyclopentene series from 36 to 26 per cent, in 3-n-alkylcyclopentene series from 51 to 44 per cent, obviously due to the increased relative importance of the side chain fragmentation reactions.

As the formation of the principal fragment ions $\left(\mathrm{C}_{5} \mathrm{H}_{7}\right)+$ proceeds with the rupture of $\mathrm{C}-\mathrm{C}$ bond located in $\beta$-position to the ring double bond in 3-alkylcyclopentenes, it is obviously promoted here. The slightly favoured formation of ions $\left(\mathrm{C}_{6} \mathrm{H}_{9}\right)+$ and $\left(\mathrm{C}_{6} \mathrm{H}_{10}\right)+$ from higher 1- $n$-alkylcyclopentenes as compared to $3-n$-alkylcyclopentenes seems, in turn, to reveal the promoted cleavage of $\mathrm{C}-\mathrm{C}$ bond beta to the ring double bond in this case.

As shown before, cyclopentene, methyl- and ethylcyclopentenes eliminate hydrogen, methyl and ethyl groups correspondingly, to give principal ions $\left(\mathrm{C}_{5} \mathrm{H}_{7}\right)+$. Metastable ions show that from higher homologs with $n_{s} \geqslant 3$ the principal ions $\left(\mathrm{C}_{5} \mathrm{H}_{7}\right)+$ may be formed via degradation of larger fragment ions $\left(\mathrm{C}_{6} \mathrm{H}_{10}\right)+$ with m/e 82 (so called McLafferty ion from 1-n-alkylcyclopentenes), $\left(\mathrm{C}_{7} \mathrm{H}_{11}\right)+$ with $\mathrm{m} / \mathrm{e} 95$ and $\left(\mathrm{C}_{7} \mathrm{H}_{12}\right)+$ with $\mathrm{m} / \mathrm{e} 96$ by elimination of the methyl group, ethylene molecule or ethyl group, respectively, as it is seen from Fig. 5. These results are in agreement with the data of K. Mayer and C. Djerassi $\left[{ }^{8}\right]$, who found in the mass spectra of 1-n-butyl- and 1-n-pentylcyclohexenes metastable ions, indicating the loss of the methyl group from the McLafferty ion. Larger fragment ions originate from molecular ions that primarily eliminate smaller alkyl groups or alkene molecules (ethylene, butylene).

The abundant ions $\left(\mathrm{C}_{5} \mathrm{H}_{8}\right)^{+},\left(\mathrm{C}_{6} \mathrm{H}_{10}\right)+$ with $\mathrm{m} / \mathrm{e} 68$, 82 , etc., show a relatively great importance of hydrogen atom rearrangements in the whole fragmentation scheme of the $n$-alkylcyclopentenes $\left(n_{s} \geqslant 4\right)$.

Many metastable ions presented in the mass spectra of most $n$-alkylcyclopentenes and indicating the loss of $\mathrm{H}_{2}$ (or $2 \mathrm{H}$ ), methyl group, acetylene or ethylene molecules a.o. from various fragment ions are characteristic for many other hydrocarbons, too.

Specific fragmentation features of $n$-alkylcyclopentenes appear in plots, showing the distribution of ion intensities with the number of carbon atoms in the ion $n_{i}$ (Fig. 6). Besides differences between $n$-alkylcyclopentane and -pentene spectra, these plots reveal some differences between 1 - and 3-n-alkylcyclopentene fragmentation patterns, too. All these graphs have three common maxima (when $n_{s} \geqslant 2$ ), corresponding to the ions with three and five carbon atoms and to the group of ions, including molecular ion. When $n_{s} \geqslant 2$, the highest maxima (sums of intensities of ions with five carbon atoms) decrease in the following order: 3-n-alkylcyclopent-1-enes $(54-62 \%)$, 1-n-alkylcyclopent-1-enes (33-50\%, e. g. about 1.5 times lower than for 3-substituted isomers). $n$-alkylcyclopentanes $(30-37 \%) . \Sigma \mathrm{C}_{5}$ for cyclopentane, methyl- and ethylcyclopentanes are smaller $(12,11,37 \%)$ than for cyclopentene, methyl- and ethylcyclopentenes $(53,43-60 \%)$ and vary within the limits of $30-32$ per cent for propyl ...n-hexylcyclopentanes.

Isomeric cyclopentenes have identical values of $\Sigma \mathrm{C}_{3}$ (at $n_{8} \geqslant 3-$ $10-15 \%)$, which are about two times lower as compared to those of 


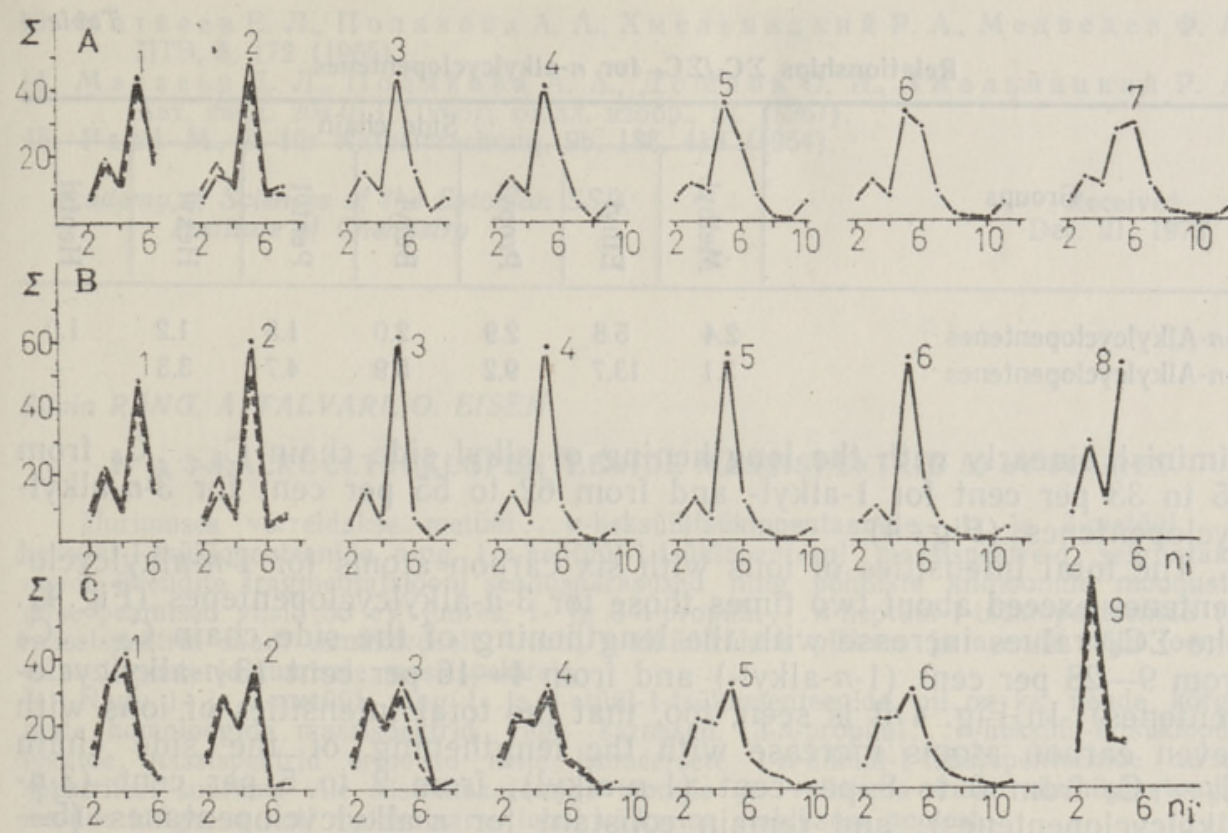

Fig. 6. Distributions of peak intensities according to the number of carbon atoms in ati ion $n_{i}$. A - 1-n-alkylcyclopent-1-enes, B - 3-n-alkylcyclopent-1-enes, C $-n$-alkylcyclo. pentanes with following side chains: 1 - methyl, 2 - ethyl, 3 - n-propyl, 4 - n-butyl, 5 - n-pentyl, $6-n$-hexyl, $7-n$-heptyl, 8 - cyclopentene, $9-$ cyclopentane. Dotted lines - literature data.

$n$-alkylcyclopentanes $(21-26 \%)$. As seen from Fig. 7 , the $\Sigma \mathrm{C}_{3}$ values decrease markedly with the addition of a methyl group to cyclopentane or cyclopentene ring (from 62 to $34 \%$ and 30 to $20 \%$, respectively) and remain constant at $n_{s}=4-6$.

Ethyl- and propylcyclopentanes show close $\Sigma \mathrm{C}_{3}$ and $\Sigma \mathrm{C}_{5}$ values $(26-28$ and $33-38 \%$, Fig. 6), but higher homologs of this series $-20-21$ and $30-32$ per cent, e. g. for the higher n-alkylcyclopentanes, the $\Sigma \mathrm{C}_{5}$ is about 1.5 times higher as compared to the $\Sigma C_{3}$. n-Alkylcyclopentenes differ by about $3-5$ times higher total intensities of ions with five carbon atoms $(33-62 \%)$ as compared to those of ions with three carbon atoms $(10-15 \%)$.

Accordingly, the maximum, corresponding to $\Sigma \mathrm{C}_{5}$ on the intensity distribution curve of cyclopentenes is about $3-5$ times higher as compared to that of $\Sigma C_{3}$, the latter being about two times higher for $n$-alkylcyclopentanes (when $n_{s} \geqslant 4$ ).

Higher $\Sigma \mathrm{C}_{6}, \Sigma \mathrm{C}_{7}$ and lower $\Sigma \mathrm{C}_{5}$ values make intensity distribution curves for 1-n-alkylcyclopentenes more diffuse as compared to those of 3-nalkylcyclopentenes, differing by sharp high maxima at $\Sigma C_{5}$. The $\Sigma C_{5}$ values
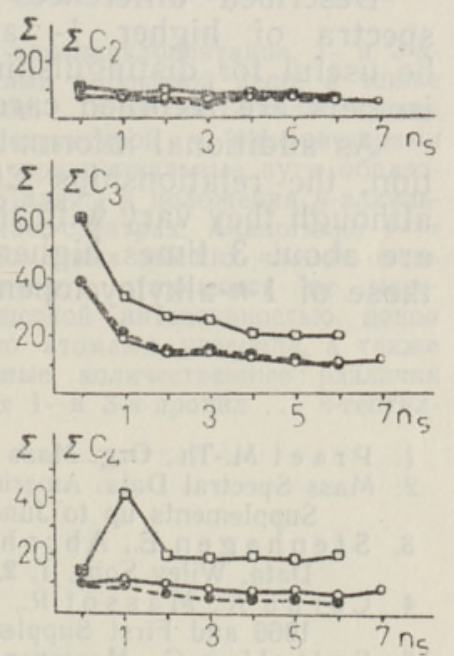

Fig. 7. Dependences of $\Sigma \mathrm{C}_{2}$, $\Sigma C_{3}$ and $\Sigma C_{4}$ on the number of carbon atoms in a side

chain $n_{s}$. 
Relationships $\Sigma \mathrm{C}_{5} / \Sigma \mathrm{C}_{6}$ for $n$-alkylcyclopentenes

\begin{tabular}{|c|c|c|c|c|c|c|c|}
\hline \multirow[b]{2}{*}{ Groups } & \multicolumn{7}{|c|}{ Side chain } \\
\hline & 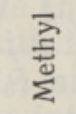 & $\underset{\text { 壱 }}{\overline{\mid}}$ & $\begin{array}{l}\bar{\lambda} \\
\text { o } \\
\text { a }\end{array}$ & $\underset{\Xi}{\vec{E}}$ & $\begin{array}{c}\overline{\vec{D}} \\
\text { D. } \\
0\end{array}$ & 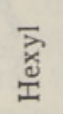 & 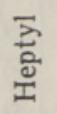 \\
\hline 1-n-Alkylcyclopentenes & 2.4 & 5.8 & 2.9 & 2.0 & 1.5 & 1.2 & 1.0 \\
\hline 3- $n$-Alkylcyclopentenes & 3.1 & 13.7 & 9.2 & 5.9 & 4.7 & 3.3 & - \\
\hline
\end{tabular}

diminish linearly with the lengthening of alkyl side chain $\mathrm{C}_{3} \ldots \mathrm{C}_{6}$ from 45 to 33 per cent for 1-alkyl- and from 62 to 55 per cent for 3 - $n$-alkylcyclopentenes (Fig. 4).

The total intensities of ions with six carbon atoms for 1-n-alkylcyclopentenes exceed about two times those for 3-n-alkylcyclopentenes (Fig. 4). The $\Sigma \mathrm{C}_{6}$ values increase with the lengthening of the side chain $\mathrm{C}_{2} \ldots \mathrm{C}_{6}$ from $9-28$ per cent (1-n-alkyl-) and from 4-16 per cent (3-n-alkylcyclopentenes). In Fig. 4 it is seen, too, that the total intensities of ions with seven carbon atoms increase with the lengthening of the side chain $\mathrm{C}_{4} \ldots \mathrm{C}_{6}$ from 6 to 8 per cent $(1-n$-alkyl), from 2 to 5 per cent $(3-n$ alkylcyclopentenes), and remain constant for $n$-alkylcyclopentanes (5$6 \%$ ).

The $\Sigma C_{2}$ and $\Sigma C_{4}$ do not markedly depend on the $n_{s}$ and vary within the limits of $6-9$ and $19-21$ per cent for $n$-alkylcyclopentanes $\left(n_{s} \geqslant 2\right)$, 5-6 and 5-11 per cent for $n$-alkylcyclopentenes (Fig. 7). $\Sigma \mathrm{C}_{8}, \Sigma \mathrm{C}_{9}$, etc. are lower than 3 per cent when molecular ions are omitted.

Described differences in ion intensity distribution between mass spectra of higher 1 - and 3-n-alkylcyclopentenes $\left(n_{s} \geqslant 2\right)$ seem to be useful for distinguishing isomeric molecules if mass spectra of both isomers are recorded carefully at equal working conditions.

As additional information, for the determination of double bond position, the relationships $\Sigma \mathrm{C}_{5} / \Sigma \mathrm{C}_{6}$ are perhaps most suitable (Table 4), although they vary with the length of the side chain. On an average, they are about 3 times higher for 3-n-alkylcyclopent-1-enes as compared to those of 1 - $n$-alkylcyclopent-1-enes (when $n_{s} \geqslant 3$ ).

\section{REFERENCES}

1. Pra et M.-Th., Org. Mass Spectrom., 4, 65 (1970).

2. Mass Spectral Data. American Petroleum Institute. Res. Project 44, New York, 1952. Supplements up to June, 30, 1960.

3. Stenhagen E., Abrahamsson S., Lafferty F. M., Atlas of Mass Spectral Data, Wiley Sons, 1, 2, 3, 1969.

4. Cornu A., Mas ot R., Compilation of Mass Spectral Data, Heyden \& Son Ltd., 1966 and First Supplement to Compilation of Mass Spectral Data, 1967.

5. S pitelle r G., Massenspektrometrische Strukturanalyse organischer Verbindungen, Verlag Chemie, GmbH, Weinheim/Bergstr., 1966.

6. B enz W., Massenspektrometrie organischer Verbindungen, Leipzig, Akademische Verlagsgesellschait, Geest \& Portig k.-G., 1969.

7. Kraft M., S p it elle r G., Org. Mass Spectrom., 2, 865 (1969).

8. M a y e r K. K., D j e r a s s i C., Org. Mass Spectrom., 5, 817 (1971).

9. Lutz G. A., Bearse A. E., Leonard J. E., Croxton F. C., JACS, 68, 4139 (1948).

10. B a ile y W. J., JACS, 79, 651 (1959).

11. Синтезы органических соединеннй, Сб. 1, М.-Л., 1950, с. 19.

12. Р а уде Х, Э йзен О., С а кс Т, Т алва ри А., Изв. АН ЭССР, Хим. Геол. 21, 3,224 (1972). 
13. Матвеев Е. Л., Поляков А. А., Хмельницкий Р. А., Медведев Ф. А., $\Pi$ ПЭ, 5,172 (1965).

14. Матвеев Е. Л., Полякова А. А., Дошлов О. И., Хмельницкий Р. А., Авт. свид. 204013 (1966); Бюлл. изобр., 21 (1967).

15. P a h 1 M., Z. für Naturforschung, $9 \mathrm{~b}, 188,418$ (1954).

Academy of Sciences of the Estonian SSR, Institute of Chemistry

Received

Dec. 21, 1972

\section{Silvia RANG, A. TALVARI, O. EISEN}

\section{1- ja 3-n-ALKOULTSUKLOPENTEENIDE MASSISPEKTRID 50 eV JUURES}

Uurimuses võrreldakse metüül...n-heksüültsüklopentaanide, 1- ja 3-metüül...nheksüül-1-tsüklopenteenide ning 1-n-heptüül-1-tsüklopenteeni massispektreid, selgitatakse nende ühendite fragmentatsiooni seaduspärasused ning pöhiliste kildioonide moodustumise peamised viisid $50 \mathrm{eV}$ juures. 1- ja 3-n-propüül ...n-heptüül-1-tsüklopenteenide (1) massispektrid saadi esmakordselt. Uuriti $n$-alküülrühma pikkuse ja asendi mōju ioonide intensiivsuste jaotumisele massispektreis.

Nagu 1- ja 3-metüül- ning 1- ja 3-etüül-1-tsüklopenteenide, nii on ka nende kõrgemate homoloogide massispektrid väga sarnased. 3-n-propüül ...n-heksüül-1-tsüklopenteenide massispektrid erinevad neile isomeersete 1 - $n$-alküül-1-tsüklopenteenide massispektritest suurema viie süsinikuaatomiga ioonide ja väiksema kuue süsinikuaatomiga ioonide hulga, samuti molekulaarse iooni väiksema stabiilsuse poolest.

Need kvantitatiivsed erinevused intensiivsuste jaotumises on kasutatavad isomeersete 1- ja 3-n-propüül ...n-heptüül-1-tsüklopenteenide (1) identifitseerimisel.

\section{Сильвия РАНГ, А. ТАЛВАРИ, О. ЭИЗЕН}

\section{0 эв МАСС-СПЕКТРЫ 1- И 3-н-АЛКИЛЗАМЕЩЕННЫХ ЦИКЛОПЕНТЕНОВ}

Исследованы и сопоставлены 50 эв масс-спектры $\mu$-алкилциклопентанов, 1 - и 3-налкилциклопентенов с метильной ... 1-н-гептил-1-циклопентена. Масс-спектры 1- и 3-н-пропил ... н-гептил-1-циклопентенов получены впервые. Установлены корреляции между структурой и масс-спектрами изомерных $\boldsymbol{H}$-алкилциклопентенов и показаны вероятные принципиальные пути образования основных осколочных ионов. Рассмотрено влияние длины и положения $\boldsymbol{н}$-алкильной боковой цепи на распределение интенсивностей в масс-спектрах. Аналогично 1- и 3-метил- и 1- и 3-этил-1-циклопентенам масс-спектры изомерных высших членов очень схожи. Масс-спектры 3-н-пропил ... $\boldsymbol{н}$-гексил-1-циклопентенов отличаются от массспектров изомерных 1-н-алкил-1-циклопентенов более высокой интенсивностью ионов с пятью и более низкой интенсивностью ионов с шестью атомами углерода, а также меньшей стабильностью молекулярного иона. Найденные количественные различия могут быть использованы при идентификации изомерных 1- и 3 - -пропил $\ldots . \mu$-гептил1 -циклопентенов. 